\title{
Synchronous emergence and mass migration in juvenile queen conch
}

\author{
Allan W. Stoner ${ }^{1}$, Romuald N. Lipcius ${ }^{2}$, Livingston S. Marshall, $\mathrm{Jr}^{2}{ }^{2}$, Ana T. Bardales ${ }^{3}$ \\ ${ }^{1}$ Caribbean Marine Research Center, 100 E. 17th Street, Riviera Beach, Florida 33404, USA \\ and Lee Stocking Island, Exuma Cays, Bahamas \\ ${ }^{2}$ Virginia Institute of Marine Science, College of William and Mary, Gloucester Point, Virginia 23062, USA \\ ${ }^{3}$ Department of Marine Science, University of Puerto Rico, Mayaguez, Puerto Rico 00708, USA
}

\begin{abstract}
An aggregation of juvenile queen conch Strombus gigas with densities exceeding 250 ind. $\mathrm{m}^{-2}$ was observed in the central Bahama Islands during April 1987. The newly documented wave-like aggregation comprised over 100000 individuals of a single year class averaging $101 \mathrm{~mm}$ in total shell length. The aggregation moved an average of $4.8 \mathrm{~m} \mathrm{~d}^{-1}$, en masse, in the direction of the ebb tidal currents. Observations between May and August 1987 showed that the mass migration was long-lived. We hypothesize the mass migration to be seasonally synchronous and to serve as a density-dependent or habitat-dependent dispersal mechanism for newly emerged 1+ year classes from centers of larval recruitment.
\end{abstract}

\section{INTRODUCTION}

The queen conch Strombus gigas Linne is a commercially important gastropod in the Caribbean Sea, Bahama Islands, and Bermuda (Abbott 1974). The snail has been fished since Arawak Indians inhabited the Caribbean region (Randall 1964, Brownell et al. 1977, 1981) yet relatively little is known about its early life stages. After metamorphosis and settlement of planktonic larvae, juveniles remain buried in sand for most of the first year of life $(0+$ year class $)$. After reaching 50 to $70 \mathrm{~mm}$ shell length, the $1+$ year class emerges, probably gradually, during warmer months before dispersing throughout shallow seagrass meadows where it lives for the next 2 to $3 \mathrm{yr}$ and feeds on algal and epiphytic foods. Sexual maturity is reached at about $3.5 \mathrm{yr}$, usually concurrent with the thickening of the broad shell lip characteristic of adults (Robertson 1959, Randall 1964, Brownell \& Stevely 1981, Egan 1985).

Two kinds of migrations are known for Strombus gigas: an ontogenetic migration of individuals to deeper waters with increasing age and size (Randall 1964, Hesse 1979, Weil \& Laughlin 1984), and a reproductive migration of adults to shallow inshore waters where they mate and lay demersal egg masses during warmer months (Robertson 1959, Randall 1964, Weil \& Laughlin 1984). Juveniles as small as $30 \mathrm{~cm}$ display oriented seasonal movements (Appeldoorn 1985).
Mass migrations are characteristic of numerous animals, particularly birds, mammals, fishes, echinoderms, and arthropods (Baker 1978, Dingle 1980, Gauthreaux 1980, Hamilton 1985, Herrnkind 1985, Scheibling 1985). Some species have single year classes that migrate en masse and subsequently disperse throughout juvenile and adult habitats (e.g. locusts, anadromous fishes, and planktonic crustaceans). The joint occurrence of mass migration and synchronous movement of a single year class is a rare and dramatic event documented in few species (Baker 1978, Dingle 1980, Gauthreaux 1980) and is unknown in benthic molluscs (Hamilton 1985).

Here we report the long-lived occurrence of an active aggregation of juvenile queen conch, reflecting synchronous mass migration and dispersal of a newly emerged year class in a marine invertebrate.

\section{STUDY SITE}

Mass migration of juvenile Strombus gigas was first observed while towing a diver over a large seagrass meadow ca $1.5 \mathrm{~km}$ west of Children's Bay Cay in the southern Exuma Cays, Bahamas $\left(23^{\circ} 45^{\prime} \mathrm{N}, 76^{\circ} 05^{\prime} \mathrm{W}\right)$. The particular seagrass meadow characteristically contains high densities of juvenile queen conch, normally between 1.0 and 2.0 conch $\mathrm{m}^{-2}$ (Wicklund et al. 1988 , 
Stoner unpubl.). The aggregation was at a depth of $3.5 \mathrm{~m}$, on a meadow of Thalassia testudinum (mean = $50.8 \mathrm{~g}$ dry wt $\mathrm{m}^{-2} ; \mathrm{SD}=13.1 ; n=4$ ) with abundant seagrass detritus (mean $=102 \mathrm{~g}$ dry $w \mathrm{t} \mathrm{m}^{-2} ; \mathrm{SD}=32$; $n=4$ ) and sparsely distributed calcareous green algae including Halimeda incrassata, Avrainvillea nigricans, and Rhipocephalus phoenix. Tides on the bank near Children's Bay Cay are semidiurnal with a range of about $1.0 \mathrm{~m}$. Tidal currents at the study site have velocities between 10 and $30 \mathrm{~cm} \mathrm{~s}^{-1}$ with the flood tide running ca $310^{\circ}$ and the ebb $130^{\circ}$ magnetic.

\section{METHODS}

The queen conch aggregation was arrayed in a long band at unusually high density. On 19 April 1987 divers placed meter-long stakes of PVC pipe in the sediment on the west side of the aggregation at $10 \mathrm{~m}$ intervals. Width of the band was measured at each stake, and the compass bearing from one stake to another was taken to provide a scale drawing and map of the aggregation (Fig. 1). Densities were determined at 2 locations within the band by counting all individuals in a given 0.5 or $1.0 \mathrm{~m}$ wide cross section. Total shell

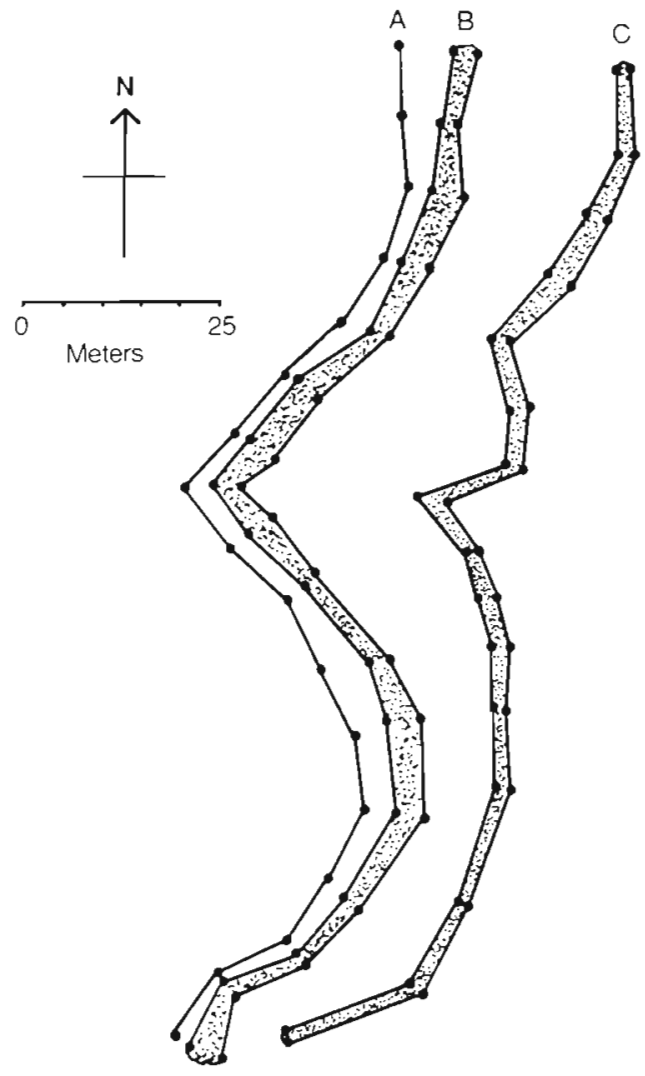

Fig. 1. Strombus gigas. Orientation and progression of the aggregation in April 1987. A: position on 19 Apr; B: 20 Apr; C: $23 \mathrm{Apr}$ lengths of the conch in these cross sections were measured with large calipers. The full procedure was repeated on $20 \mathrm{April}, 23 \mathrm{April}$, and partially during repeated measurements in May and June.

Densities of conch in front of and behind the aggregation were determined on 21 April, by counting the numbers of individuals in circular plots with radii of 5.0 $\mathrm{m}$, centered at $10.0 \mathrm{~m}$ from the edge of the aggregation. Two plots were counted on each side of the aggregation.

\section{RESULTS}

The queen conch aggregation was composed of juveniles with a mean shell length of $101 \mathrm{~mm}$ (SD = $13 \mathrm{~mm} ; n=256$; range $=67$ to $145 \mathrm{~mm}$ ). Total length of the conch aggregation was $160 \mathrm{~m}$ on 19 and $20 \mathrm{April}$, reducing to $150 \mathrm{~m}$ on 23 April. Average width was $2.4 \mathrm{~m}(\mathrm{SD}=1.1 ; n=16)$ on 19 April, $3.2 \mathrm{~m}(\mathrm{SD}=0.8$; $n=17)$ on 20 April, and $2.3 \mathrm{~m}(\mathrm{SD}=0.5 ; n=16)$ on 23 April. Analysis of variance $(F=4.492, p=0.017)$ and Newman-Keuls multiple range test indicated that widths of the wave were significantly greater on 20 April than on 19 and 23 April when widths were similar $(p>0.05)$. Observation of greater mean width on 20 April reflected greater dispersion of individuals as shown by lower densities on that date (Table 1). Total surface area of the aggregation was $388 \mathrm{~m}^{2}$ on 19 April and $500 \mathrm{~m}^{2}$ on 20 April. Based upon these dimensions and densities in the aggregation on the respective dates, the total number of individuals was estimated to be between 123000 and 136000 .

Over the April study period, the aggregation moved to the southeast, $\left(\right.$ mean $=109^{\circ}$ magnetic SD $=33^{\circ} ; n=$ 17) (Fig. 1), close to the direction of the ebb tide. In the first $19 \mathrm{~h}$ of observation, total movement averaged $3.3 \mathrm{~m}(\mathrm{SD}=1.8 \mathrm{~m} ; n=17$ ) (Table 1 ), giving an average advance of the wave-like aggregation of $17.4 \mathrm{~cm} \mathrm{~h}^{-1}$. The mean movement over $5 \mathrm{~d}$ was $23.9 \mathrm{~m}(\mathrm{SD}=6.8$,

Table 1. Strombus gigas. Progression of the conch aggregation across a seagrass meadow in the Exuma Cays, Bahamas, from April to July, 1987. Values for densities are mean \pm standard deviation $(n)$

\begin{tabular}{|ccc|}
\hline Date & $\begin{array}{c}\text { Rate of progression } \\
\left(\mathrm{m} \mathrm{d}^{-1}\right)\end{array}$ & $\begin{array}{c}\text { Density in aggregation } \\
\left(\text { no } \mathrm{m}^{-2}\right)\end{array}$ \\
\hline $19 \mathrm{Apr}$ & - & $319 \pm 97(2)$ \\
$20 \mathrm{Apr}$ & 3.3 & $271 \pm 7(2)$ \\
$23 \mathrm{Apr}$ & 4.8 & $104 \pm 22(4)$ \\
$17 \mathrm{May}$ & 4.4 & -1. \\
$30 \mathrm{May}$ & 3.1 & $51 \pm 24(5)$ \\
$15 \mathrm{Jun}$ & 2.7 & $40 \pm 15(4)$ \\
$30 \mathrm{Jun}$ & 2.7 & 0 \\
$26 \mathrm{Jul}$ & Dispersed &
\end{tabular}




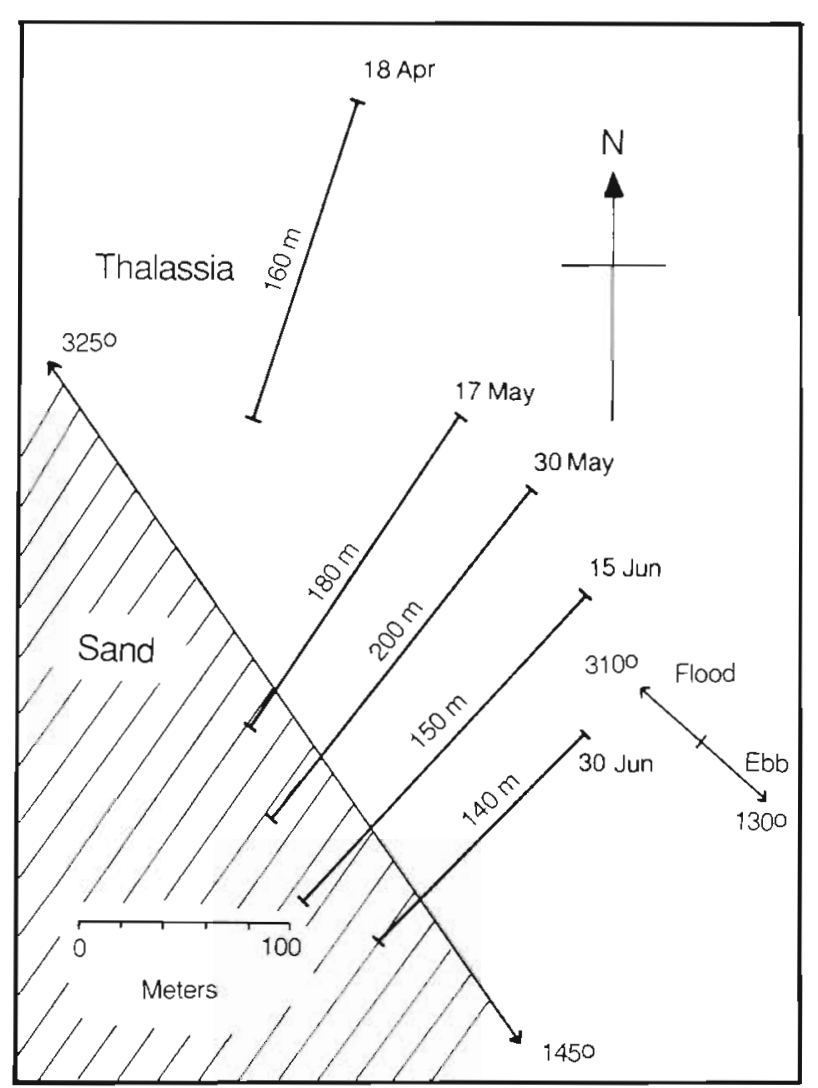

Fig. 2. Strombus gigas. Progression of the aggregation between April and June 1987. Lines indicate the positions and lengths of the aggregation on individual dates

$n=16$ ), which equals $4.8 \mathrm{~m} \mathrm{~d}^{-1}$. Most of the conch in the aggregation were oriented with the ebb flow, in the same direction as the group movement.

Observations of the aggregation between May and July 1987 showed that the aggregation was long-lived and continued to move in the direction of the ebb tide (Fig. 2), while undergoing slow dispersion. On 17 May the wave was $100 \mathrm{~m}$ from the 18 April position. The wave advanced $40 \mathrm{~m}$ in each of the ca $2 \mathrm{wk}$ intervals from 17 to 30 May, 30 May to 15 June, and 15 to 29 June. In May and June, the west end of the aggregation moved onto an adjacent sand bank, where the conch appeared to disperse quickly.

Over the period of observation, density in the aggregation decreased logarithmically (natural log of density) with date $\left(R^{2}=0.980 ; F=148.171 ; p<0.001\right)$ (Table 1). At the end of July 1987, the aggregation had dispersed entirely, with juvenile conch densities reaching zero ca $250 \mathrm{~m}$ from the original position in April.

The aggregative and migratory behavior resulted in dispersal of the juvenile gastropods over the nursery ground as individuals left the aggregation in large numbers. The April survey of conch populations in front of and behind the high-density band showed that juvenile conch were more than 6 times as dense behind the aggregation (2.42 conch $\left.\mathrm{m}^{-2} ; \mathrm{SD}=0.72 ; n=2\right)$ as in front of it $\left(0.375\right.$ conch $\left.\mathrm{m}^{-2} ; \mathrm{SD}=0.106 ; n=2\right)$. Conch in front of and behind the aggregation were oriented randomly.

Other smaller aggregations of juvenile queen conch were observed in June 1987, near Lee Stocking Island, Exuma Cays. In February through March 1988, an aggregation of 2 yr old conch was found near Children's Bay Cay.

\section{DISCUSSION}

Densities of juvenile and adult queen conch as high as $2.1 \mathrm{~m}^{-2}$ have been reported, but over expansive areas naturally occurring field densities are generally 1 conch $\mathrm{m}^{-2}$ or less (Alcolado 1976, Hesse 1979, Wood \& Olsen 1983, Weil \& Laughlin 1984, Iversen et al. 1987). Piles of conch, as much as 3 individuals deep, have been observed in the Turks and Caicos (Hesse 1979), but in total numbers of only 9 to 22. It was suggested the aggregations formed as a means of protection from wave surge in fall and winter. Relatively small reproductive aggregations have been noted in Venezuela (Weil \& Laughlin 1984) and in the Bahamas (Wicklund et al. 1988), but these are unquantified. The occurrence of an aggregation of over 100000 juvenile queen conch in densities exceeding $250 \mathrm{~m}^{-2}$ is a new observation.

The aggregation and mass migration of juvenile queen conch are unlikely to have been stimulated by mechanical disturbance in the relatively calm summer months, or to be related to reproduction since these individuals would not be sexually mature for at least 2 more yr. Comparison of the size range found in the aggregation with growth curves from other studies (Berg 1976, Weil \& Laughlin 1984) showed that the conch were ca 1 yr old. Uniform small size and lack of fouling on shells suggested that the conch in the aggregation were similar in age and had recently emerged. The aggregation may have been promoted by seasonally synchronous (over days to weeks) emergence from the infaunal habitat of the first year, possibly cued by some environmental characteristic such as increasing water temperature, lengthening photoperiod, or decreasing wave disturbance.

We hypothesize that the juveniles emerged from a shallow unvegetated sand bank $50 \mathrm{~m}$ west of the study site in late March, since the $0+$ year class typically inhabits sand flats adjacent to seagrass beds (Robertson 1959, Randall 1964). Migration onto the seagrass bed, therefore, represents an ontogenetic shift of habitat from soft sand flats amenable to burrowing in the first year of life to vegetated substrata where detritus and macroalgae are grazed. 
The wave-like aggregation could form through various mechanisms. If the juveniles move from soft sand habitats to seagrass meadows, as has been hypothesized (Robertson 1959, Randall 1964), the aggregation may simply form at the boundary between these habitats and move across the seagrass meadow as a means of dispersing the concentrated $0+$ year class away from food-limited areas. This kind of mass movement occurs in sea urchins which strip areas of vegetation (Lawrence 1975, Chapman 1981, Harrold \& Reed 1985). Conversely, aggregation and migration may be behaviors characteristic of queen conch in certain developmental stages. Locomotory activity increases with conch density in Strombus gigas (Siddall 1984), and orientation and migratory behavior may also be triggered by high conch density.

In an unrelated field enclosure experiment (Stoner unpubl.), conch taken from the migration and enclosed at high densities immediately oriented in the direction of the ebb tidal current and moved to the southeast side of each enclosure. This orientation was maintained for 1 wk or more, while the tendency disappeared within $24 \mathrm{~h}$ in enclosures with lower densities. No orientation occurred in conchs held at natural field densities (i. e. in treatments containing 2.0 conch $\mathrm{m}^{-2}$ ). Hence, the oriented migrating behavior may be promoted by high conch densities, similar to that in spiny lobster (Herrnkind 1985). In 1988, no aggregations of 1 yr old conch have been observed in the Children's Bay Cay area; this may be related to population densities one-half the values found in 1987 (Stoner unpubl.).

Progression of the conch aggregation was probably related to water temperature, wave action, and abundance of food. Observations in 1988 were that daily progression of an aggregation of $2 \mathrm{yr}$ old conch was inhibited by increasing wave disturbance and by falling temperatures. Under these conditions, the conch stopped movement, buried the edge of the shell, and became oriented in random directions. Also, it appeared that forward progression was a function of food availability. In local areas where seagrasses were heavily epiphytized or where the bottom had significant stands of green algae or macrodetritus, the mass migration was slower than in areas where these food items were less abundant. The non-linear shape of the April 1987 aggregation may have been a function of different progression rates along its long axis.

Evolutionary mechanisms related to aggregation and migration in Strombus gigas may only be hypothesized. Predation rates on small conch are high (Appeldoorn 1984, 1985, Iversen et al. 1986) and may be reduced by high density aggregations. Orientation with the ebb currents may be energetically advantageous and direct the conch in the typical offshore migration associated with ontogenetic development.
Localized juvenile conch populations, and the fact that over half a million juveniles occur year after year in a specific habitat less than $0.5 \mathrm{~km}^{2}$ in total surface area (Wicklund et al. 1988) allows us to advance the hypothesis that patterns of field distribution in conch may result from dispersal from specific centers of recruitment. In effect, small areas with particular hydrographic and sedimentary features may serve as key sources of juveniles and adults for much larger areas. Clearly, the more general accurrence of such centers of recruitment should be investigated along with their ecological and fisheries significance.

Given the long duration of such a large aggregation of queen conch in shallow waters, it is surprising that such events have not been documented previously. However, mass migration in queen conch may only occur when density is high, a condition which is becoming uncommon in the heavily fished Caribbean region (Adams 1970, Brownell et al. 1977).

Acknowledgements. We thank R. Wicklund, Director of the Caribbean Marine Research Center, for introducing us to the conch nursery areas near Lee Stocking Island and for logistical support in the study of conch aggregations. B. L. Olla served as an advisor to our work on Strombus. We thank G. Wenz, B. Bell, G. Van Zant, and the staff members at the Caribbean Marine Research Center who helped with logistics and accomodations during our trips to Lee Stocking Island. This project was supported by a grant from the Office of Undersea Research, National Oceanic and Atmospheric Administration, US Department of Commerce, R. S. Appeldoorn, D. L. Ballantine, and B. A. Buchanan, E. S. Iversen, G. Wenz, and R. I. Wicklund provided critical reviews of the manuscript. First authorship was decided by a coin toss between A. W. S. and R. N. L.

\section{LITERATURE CITED}

Abbott, R. T. (1974). American seashells, 2nd edn. Van Nostrand Reinhold, New York

Adams, J. E. (1970). Conch fishing industry of Union Island, Grenadines, West Indies. J. trop. Sci. 12: 279-288

Alcolado, P. M. (1976). Crecimiento, variaciones morfologicas de la concha y algunas datos biologicos del cobo Strombus gigas L. (Mollusca, Mesogastropoda). Acad. Cienc. Cuba, Ser. Biol. 34: 1-36

Appeldoorn, R. S. (1984). The effect of size on mortality of small juvenile conchs (Strombus gigas Linne and $S$. costatus Gmelin). J. Shellfish Res. 4: 37-43

Appeldoorn, R. S. (1985). Growth, mortality and dispersion of juvenile laboratory-reared conchs, Strombus gigas and $S$. costatus, released at an offshore site. Bull. mar. Sci. 37: 785-793

Baker, R. R. (1978). The evolutionary ecology of animal migration. Holmes \& Meier, New York

Berg, C. J., Jr (1976). Growth of the queen conch, Strombus gigas, with a discussion of the parcticality of its mariculture. Mar. Biol. 34: 191-199

Brownell, W. N., Berg, C. J., Jr, Haines, K. C. (1977). Fisheries and aquaculture of the conch, Strombus gigas, in the Caribbean. FAO Fish. Rep. 200: 59-69 
Brownell, W. N., Stevely, J. M. (1981). The biology, fisheries, and management of the queen conch. Strombus gigas. Mar Fish. Rev. 43: 1-12

Chapman, A. R. O. (1981). Stability of sea urchin dominated barren grounds following destructive grazing of kelp in St. Margaret's Bay, Eastern Canada. Mar. Biol. 62: 307-311

Dingle, H. (1980). Ecology and evolution of migration. In Gauthreaux, S. A., Jr (ed.) Animal migration, orientation, and navigation. Academic Press, New York, p. 1-101

Egan, B. D. (1985). Aspects of the reproductive biology of Strombus gigas. M. Sc. thesis, Univ. British Columbia, Vancouver

Gauthreaux, S. A., Jr (1980). The influences of long-term and short-term climatic changes on the dispersal and migration of organisms. In: Gauthreaux. S. A., Jr (ed.) Animal migration, orientation, and navigation. Academic Press, New York, p. 103-174

Hamilton, P. V (1985). Migratory molluscs, with emphasis on swimming and orientation in the sea hare Aplysia. In: Rankin, M. A. (ed.) Migration mechanisms and adaptive significance. Contr. Mar. Sci., Univ. Texas, Suppl. 27: $212-226$

Harrold, C., Reed, D. C. (1985). Food availability, sea urchin grazing, and kelp forest structure. Ecology 66: 1160 -1169

Herrnkind, W. F. (1985). Evolution and meachanisms of mass singlefile migration in spiny lobster: synopsis. In: Rankin, M. A. (ed.) Migration, mechanisms and adaptive significance. Contr mar. Sci., Univ. Texas, Suppl. 27: $197-211$

Hesse, K. O (1979). Movement and migration of the queen conch, Strombus gigas, in the Turks and Caicos Islands. Bull. mar. Sci. 29: 303-311

Iversen, E. S., Jory, D. E., Bannerot, S. P. (1986). Predation on queen conchs, Strombus gigas, in the Bahamas. Bull. mar. Sci. 39: 61-75

Iversen, E. S., Rutherford, E. S., Bannerot, S. P., Jory, D. E. (1987). Biological data on Berry Islands (Bahamas) queen conchs, Strombus gigas, with mariculture and fisheries management implications. Fish. Bull. U. S. 85: 299-310

Lawrence, J. M. (1975). On the relationships between marine plants and sea urchins. Oceanogr mar. Biol. A. Rev. 13: 213-286

Randall, J. E. (1964). Contributions to the biology of the queen conch, Strombus gigas. Bull. mar. Sci. Gulf Caribb. 14: 246-295

Robertson, R. (1959). Observations on the spawn and veligers of conchs (Strombus) in the Bahamas. Proc. malac. Soc. Lond. 33: 164-171

Scheibling, R. E. (1985). Directional movement in a sea star (Oreaster reticulatus): adaptive significance and ecological consequences. In: Rankin, M. A. (ed.) Migration, mechanisms and adaptive significance. Contr. mar. Sci., Univ. Texas, Suppl. 27: 244-256

Siddal, S. E. (1984). Density-dependent levels of activity of juveniles of the queen conch, Strombus gigas Linne. J. Shellfish Res. 4: 67-74

Weil, M. E., Laughlin, G. R. (1984). Biology, population dynamics, and reproduction of the queen conch, Strombus gigas Linne, in the Archipielago de Los Roques National Park. J. Shellfish Res. 4: 45-62

Wicklund, R. I., Hepp, L. J., Wenz, G. A. (1988). Preliminary studies on the early life history of the queen conch, Strombus gigas, in the Exuma Cays, Bahamas. NOAA Symp. Series for Undersea Research. 6(2): in press

Wood, R. S., Olsen, D. A. (1983). Application of biological knowledge to the management of the Virgin Islands conch fishery. Proc. Gulf Caribb. Fish. Inst. 35: 112-121 